\title{
Can the university save Europe?
}

Citation for published version (APA):

Ritzen, J. (2012). Can the university save Europe? Maastricht University. https://doi.org/10.26481/spe.20120608jr

Document status and date:

Published: 08/06/2012

DOI:

10.26481/spe.20120608jr

Document Version:

Publisher's PDF, also known as Version of record

\section{Please check the document version of this publication:}

- A submitted manuscript is the version of the article upon submission and before peer-review. There can be important differences between the submitted version and the official published version of record.

People interested in the research are advised to contact the author for the final version of the publication, or visit the DOI to the publisher's website.

- The final author version and the galley proof are versions of the publication after peer review.

- The final published version features the final layout of the paper including the volume, issue and page numbers.

Link to publication

\footnotetext{
General rights rights.

- You may freely distribute the URL identifying the publication in the public portal. please follow below link for the End User Agreement:

www.umlib.nl/taverne-license

Take down policy

If you believe that this document breaches copyright please contact us at:

repository@maastrichtuniversity.nl

providing details and we will investigate your claim.
}

Copyright and moral rights for the publications made accessible in the public portal are retained by the authors and/or other copyright owners and it is a condition of accessing publications that users recognise and abide by the legal requirements associated with these

- Users may download and print one copy of any publication from the public portal for the purpose of private study or research.

- You may not further distribute the material or use it for any profit-making activity or commercial gain

If the publication is distributed under the terms of Article $25 \mathrm{fa}$ of the Dutch Copyright Act, indicated by the "Taverne" license above, 


\section{Maastricht University}

Oratie

Prof. dr. ir. J o Ritzen

Faculty of Humanities and Sciences

\section{Can the university save Europe?}




\section{Can the university save Europe?}

Taken for a ride or taking the bull by the horns

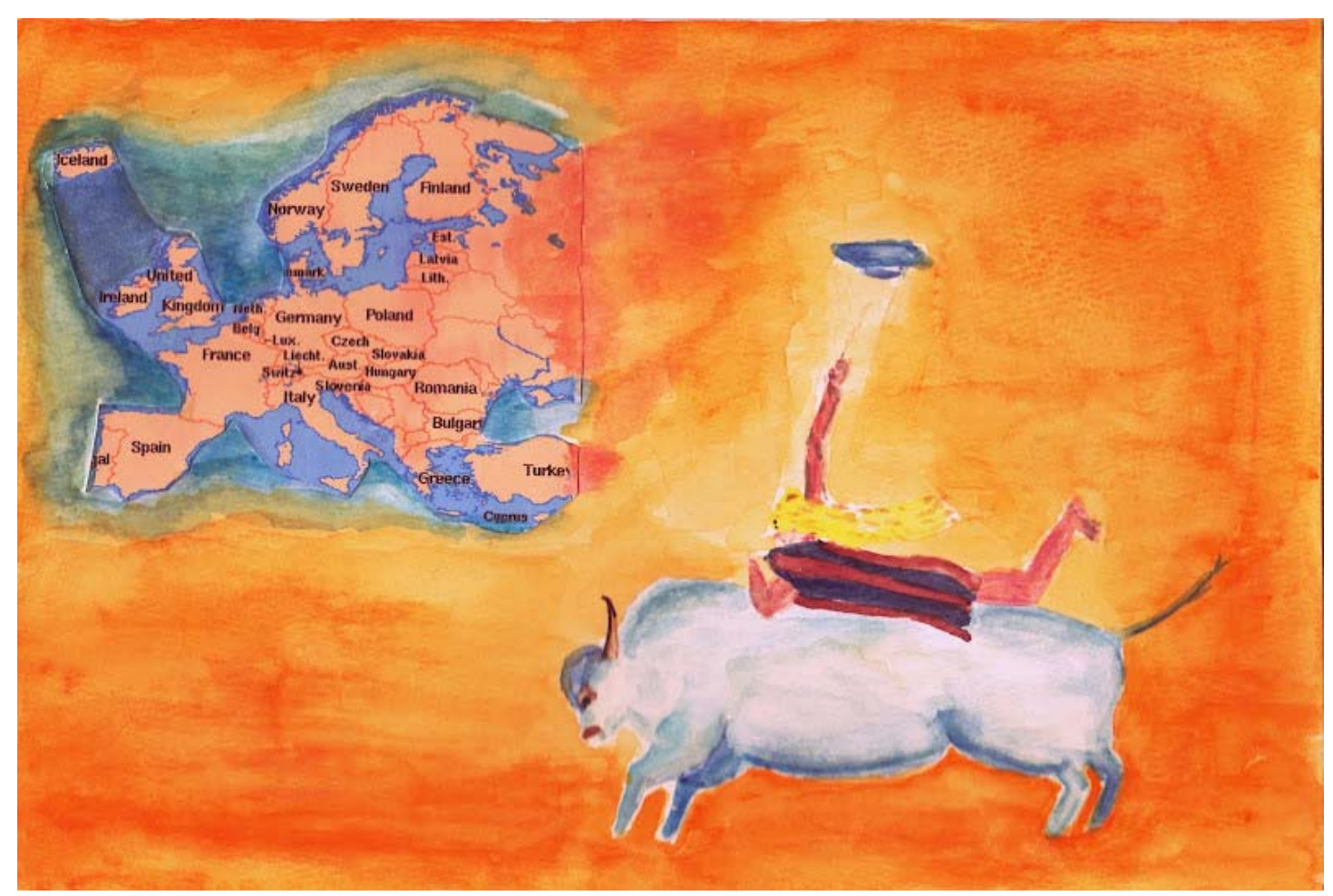

Inaugural Lecture, Jo Ritzen, June 8, 2012. 
Table of Contents.

1. Oratio pro domo: well-conceived self-interest as guiding Europe.

2. Europe's bumpy ride in hope and optimism.

3. Europe's golden age need not be over yet.

4. Universities as drivers of economic growth.

5. How to realize the promises of European universities.

6 . The bull by the horns.

7. My gratitude.

8. References. 


\section{Oratio pro domo: well-conceived self interest as guiding Europe.}

Europe should take the bull by the horns. Continued and intensified European cooperation is the key to welfare for European citizens in the future. Higher education and research are - even more than in the past - the major engines of increased sustainable welfare.

In the recent past Europe let itself be taken for a ride. Europe seemed to revert back to the Greek legend in which the Maiden Europe was abducted by Zeus, who had disguised himself as a bull. And Maiden Angela Europe and her choir of European leaders seemed unable to take the bull by the horns, to save itself.

Saving Europe means that Europe determines its own destiny, duly aware of the rumblings and fuming of the vessel earth and very much part of globalization. But its citizens should choose their own European course, their own approach which reflects the distinctness of their civilization.

Saving Europe will take more than a change in the European Treaty to instill a sense of responsibility among all EU members to sing the same socio-economic and cultural song and not to fall out of tune in the choir due to the false notes of too high budget deficits or other evils. Saving Europe is about the creation of the music which will advance optimism, positivity, the feeling of security and of vibrancy. Sustainable economic growth is part of the libretto. But there are also arias about the way economic growth leads to more hope and optimism.

Can the university save Europe? Or better: can the university save Europe again? The university saved Europe by being the cradle and foster parent of enlightenment in the 18th century (Israeli, 2010). It saved and shaped Europe. The Enlightenment shaped the European soul and European societies, bestowing on Europe a special kind of civilization - in which every human being counts.

This is the Europe which has enjoyed after the Second World War a period of historically unprecedented economic growth (Gill and Raiser, 2012).

There is no reason to resign ourselves to fatalism: to assume the golden days are over. Europe still has much going for it, but now needs to adapt further to the changes in society which have occurred worldwide, using its assets of social cohesion and strong governance. 
European universities are now enrolling more students than ever, they are teaching students better than ever before, and are more productive in research. But that is not enough to save Europe. Universities could contribute much more through their education to sustainable economic growth if they were better empowered and at the same time exposed to European competition. This means rewarding successful degree courses and closing down unsuccessful ones.

The intellectual leadership role of universities seems to have dried up and needs to be redeployed to reinvigorate Europe. Universities need to be better heard on major societal questions and should come up with possible answers. In particular the role of social science and humanities research could be strengthened. Releasing the powers of European competition could also do wonders for research.

Entrepreneurship is a neglected item in university education and research. Our future jobs will be created by entrepreneurship within existing firms or by new startups. Universities have done as yet little to take this notion on board in disciplines other than (business) economics and business administration. Entrepreneurship training should be a part of all disciplines, following up on a far greater emphasis on entrepreneurship throughout the education system.

In this way universities could play a substantial role in reinvigorating Europe. The level of innovation might increase, and so would sustainable growth. This is likely to be accompanied by continued wage inequalities. In the broader perspective of the Maiden Europe groping for the horns of the bull, and so deciding on her own direction, one needs to reflect on measures to avoid such a rise in income inequality and the associated loss of social cohesion.

In an inaugural lecture you announce what you have in mind in sharing with students and colleagues in education and research. It is more over a cause for celebration of the newly acquired (in my case re-acquired) right to guide people to the doctorate.

This lecture is a demonstration of how my field of appointment (the "international economics of science, technology and higher education") can contribute to one of the major questions of our times: how to deal with Europe as the house of our future in which it is pleasant to be, which is vibrant, which excites and where young people from all around the world want to go to and where also the older people feel at ease. It is an example of how research and education can contribute to a better world, as research and education are meant to be! 
It is an oratio pro domo in the sense that we all can benefit from a better course for Europe. The roofs of the houses of EU member-states are leaking under the torrents of globalization. Common EU policies could reinforce these roofs and mend the leaks. Saving Europe is in our own interest.

\section{Europe's bumpy ride in hope and optimism.}

\section{Quiz Question:}

Why and from whom/what would Europe need saving?

Choose from the following answers:

1. There is no need to save Europe. Things are great the way they are.

2. Not to become irrelevant in world trade and lose the potential of sustainable economic growth. It is saving from itself, from its indolence.

3. The Chinese will otherwise buy us up and treat us as a region for exploitation.

4. We are anyway doomed: the last days of an empire.

Europe is experiencing a bumpy ride. The appreciation for Europe as an example for emerging economies and developing countries has waned in the past decade. Sometimes it is now pitifully looked down at as a continent in decline. This appreciation is the mirror image of the feelings of Europeans with an increasing pessimism, an increasing lack of self-confidence and with an increasing hesitation on further European cooperation, reflected in the positions of political parties in Europe. Something we call Euro-skepticism is in the European air, which goes hand in hand with increased nationalism and a whiff of xenophobia, while the objective circumstances call for more integration as a safeguard against the odds of globalization.

At the surface, Europe seems to be in a good shape. If we ask the citizens: “do you consider your country's membership of the EU as a good thing” then the overwhelming majority of European citizens (almost 80\%) say “yes". This did not change between 2000 and 2010, contrary to what we observe as increasing Euroskepticism.

Also in 2004 no less than 59 \% of the European citizens describe themselves as "Europeans", 69\% feel an attachment to Europe and 72\% are proud to be a 
European (Fuchs et al, 2009, p. 99). A European identity is not felt to be contradictory to a national identity.

European citizens did not believe in 2004 that Europe had gone too far in appropriating the policy domains of global security and migration, but they are critical in the Europeanization of the policies of social and domestic security (Truedinger, 2009, p.151).

The percentage of citizens who think that the expansion has gone too far has only slightly increased from 24 to 27\% between 2004 and 2008 while at the same time the proponents of more expansion have decreased from $36 \%$ to $33 \%$.

So on the surface the Europe from before the 2011 crisis was in a good shape, even though it was a bumpy ride, with ups and downs (as Lubbers and Scheepers, 2010, show for the period 1994-2004).

However, when scratching the surface one sees that the percentage of citizens who think that "their country's membership of the EU is a bad thing" is on the increase. The percentage of those who were ambivalent about Europe, or didn't express an opinion has declined and converted into a "no" to Europe. This development is particularly prominent in the old EU of the 15.

European institutions are the ire of the European citizen. People may still like Europe, but they dislike increasingly the European institutions, like the Parliament, the Commission, the Council and the Courts. Distrust is on the increase in the period 2000-2009. In 2009 some 39\% of the population tended to trust EU institutions (down from $43 \%$ in 2000), while the distrusters formed almost the same size (32\% up from $24 \%$ in 2000).

But the most disconcerting is the increased pessimism (even before the present crisis): the expectations of Europeans for the next 12 months on their life in general, on the economy in the own country, the financial situation in the household, the employment in the country and the personal job situation show an almost doubling of the level of pessimism at the start of the century. ${ }^{1}$

This is all happening at a time when more Europe is the only way to retain a strong social, economic and cultural position. In March 2012 I organized the Vibrant Europe Forum. This forum found its conclusion in a declaration, which expresses the desire for a better Europe as follows:

\footnotetext{
${ }^{1}$ Europe is not the only continent which suffers from increased pessimism: it is also the case in the US. (Ritzen and Zimmermann, 2012). This all is in sharp contrast to China, where optimism reigns.
} 
"The relative power of even the largest EU member states has dramatically diminished. In the old world of the G7 more than half the members were EU member states. Today the G20 has become the major forum for world economic debates and only one fifth of the members are European. With Europe only amounting to some $8 \%$ of the world population, individual European countries will have less and less leverage on the world stage. Europe as a whole faces the choice of either hanging together to remain influential and relevant, or succumbing one by one to the whims and demands of other world powers" (www.vef.merit.unu.edu).

How can we explain -against this background- the increasing Euro-skepticism and European pessimism? Why the nationalism which is a form of shooting yourself in the foot? And why this support for slightly xenophobic parties in EU countries that has already visibly led to a decrease of their competitiveness? Euro-skepticism and nationalism appear at worst suicidal and at best masochistic.

The answers are presumably that it is a combination of disappointment in the realization of expectations coined in the term "uneasiness" or "disgruntlement" (“onbehagen”) (Koenis, 2012). As part of my research at the Institute for the Study of Labor (IZA) in Bonn, which operates the largest network of economists around the world, I try to understand how objective circumstances, like the citizen's income and job security may have impacted Euro-skepticism and the increase in pessimism.

Initially, in the small Europe of the European Community for Coal and Steel, European citizens felt that Europe was good for them, in terms of income. This enthusiasm remained after the broadening to the European Community. It even increased with the convenience to travel abroad without showing their passport, to travel without having to change money and to study abroad. The growth in income in those years, the decreasing inequality in income within member countries and the convergence in incomes between poorer and richer member states were presumably driving forces in the support for further European cooperation.

The past ten to fifteen years showed the same continued growth and convergence, but with one major difference: job security of lower skilled labor decreased and income inequality started to rise, albeit slowly (OECD, 2008, 2011). In such a case one would expect that income groups at the lower end of the distribution would increasingly question "Europe" as an investment which pays dividends for them. "Europe" became indeed less popular among people with lower incomes who felt threatened in their job security and became more concerned about crime (Kufer, 
2009, p. 47). Euro-skepticism emerged, in particular in countries who were net payers to the EU.

It is not simple for the well informed researcher, let alone for the individual citizen, to distinguish between the impact of the gradually increased role of Europe on individual circumstances (like on the perception of safety, on income and on employment) and the impact of other factors, like the increased globalization with increased trade and international financial streams, the increased impact of information and communication technology on society, the increased immigration and the decreased half-life time of products.

We assume that citizens, when they are asked whether they believe in Europe, lump all these together and add other factors that have impacted their lives. They express an attitude towards Europe based on the development in their income, relative to that of others in society and in the degree of income security. This assumption seems appropriate as increased Euro-skepticism and the increase in pessimism took place at a time when inequality in the distribution of income and of wealth increased and income security decreased.

Hope can be based on the perception of one's own position ("I think this society will give me a chance of betterment”). It might also be based on what one thinks one’s children can achieve ("my children will do better than I do"). Social mobility benefits society by providing hope for their children for those who themselves have not reached the upper social tiers. The new generation might do better than their parents. This is a win-win in our societies where the full development of the talents of children has so much to offer for society at large. But social mobility appears in Europe to be on the decline, possibly through an increasing segregation of schools between those for the children of the well-to-do and schools for other children (Ritzen, 2011).

Saving Europe means to restore optimism and hope, with higher sustainable economic growth, a more equal distribution of income and wealth and with increased social mobility, while at the same time restoring trust in European institutions through a better organization of Europe, closer to the citizen .

\section{Europe's golden age need not be over yet.}

Quiz Question: 
What does it take to bring sustainable income growth in Europe to a level of say $2 \%$ per capita per year?

Choose from the following answers:

1. Greening the economy in a European approach.

2. European rules on macro-economic policy.

3. European labor market policies.

4. Invest in knowledge that translates into business.

Europe has achieved an unprecedented economic growth in the period 1820 up to 2009. Total accumulated economic growth has been higher in Europe than in any other part of the world (Gill and Raiser, 2012). After the Second World War Western European incomes converged quickly towards those in the United States. Some 200 million people in the poorer south and east grew closer to those in advanced Europe. Another 100 million in Southeastern Europe are already benefiting from the same aspirations and similar institutions that have helped almost half a billion people achieve the highest standards of living on the planet.

Europe's golden age need not be over yet if it pays attention to the challenges and weaknesses. The decrease in and ageing of the population is a major challenge. On current immigration and work participation trends Europe will lose about 50 million workers (15\% of the total labor force of today) over the next five decades. In the 2030s alone, the labor force will fall by 15 million people (or almost 5\% of the present total of the labor force). This would be no problem if the number of mouths to be fed or the hands and minds to be supplied with iPads would decline by the same number. However, that is not the case: the ratio of productive workers to the population is declining. This trend was foreseen. In my previous inaugural lecture at the Erasmus University in Rotterdam in 1983, I pleaded for a gradual, anticipated deferment of the retirement age by the year 2000 (Ritzen 1983) ${ }^{2}$. Such a deferment of the retirement age is still needed, together with more female participation, and longer working time to offset the trend of the declining ratio of the working population to the total population. Immigration, based on a regulated admission of non-Europeans who want to contribute to European society could be a win-win for the migrant and for Europe. But all these measures together are presumably not going to completely

\footnotetext{
${ }^{2}$ ) It took almost 30 years before the message hit home. Hopefully the present lecture will have a more immediate impact.
} 
compensate the trend. The greatest opportunity then is in raising the productivity level of our work force through education and research.

In the Vibrant Europe Forum many opportunities for Europe to do better were discussed:

- Greening the economy in a competitive way with other parts of the world, by the introduction of a CO2 tax on all products, imported or locally produced, building on the present emission trading scheme.

- Coherence of macro-economic policy in the EU. This can only be brought about through greater EU oversight of budget deficits in such a way that the automatic stabilizers of Government- and welfare expenditures can continue to do their work. - An EU wide financial framework. Systemically important, high risk, pan-European banks should be better capitalized and less complex in their structures and opaque in their operations. They must be supervised by regulation at the EU level with the legal power and financial means to restructure failing banks. Long term shareholding should be rewarded with extra votes or dividend. Publicly listed banks, that meet clearly defined public purposes, deserve protection from unfriendly takeovers.

- EU wide infrastructure policies in public transport, energy transport, and information and communication technology.

- Full employment and increased social mobility.

- A more balanced package of work conditions for those with life time contracts and those with more flexible or temporary contracts. Labor market policy has to recognize that jobs defined as a certain set of tasks are disappearing more rapidly as a result of technological and market change. The costs of a commitment to lifetime employment may simply be unsupportable for some employers.

- Increasing labor mobility in the EU by breaking down the barriers between countries in pension regulations and other social security arrangements.

But the biggest of all opportunities is that the university saves Europe, by inducing higher levels of innovation through the improvement of the quality of the hands and minds, by stimulating entrepreneurship and the strengthening of public research, in an environment in which the pervasive bureaucratic impediments for entrepreneurship (so well documented in the annual World Bank document: "Doing Business") are simply and quickly swept away.

\section{Universities as drivers of economic growth.}


Quiz Question:

Why are graduates important on the labor market?

Choose from the following answers:

1. They dress well and know the latest jokes.

2. They have become central in the production process because they are aware of the complexities of society, in terms of marketing, finance, technology, communication etc.

3. They have learned to be persistent (otherwise they would never have completed their study).

4. They can deal with international clients and suppliers.

Universities can be far more influential in promoting sustainable economic growth then they have been in the past. The Manifesto: Empower European Universities (2010) signed by some twenty influential European leaders in higher education and research makes this assertion, against the accepted background that the contribution of higher education to economic growth has increased dramatically in the past three decades.

Already in the 1975 Tinbergen formulated "the race between technology and education". Technology was the race cart which since the industrial revolution has been what economist call "labor-saving", that is allowing for fewer hours of work of unskilled labor in the making of a product, by using the technological advances of production lines or robots. This technological progress has brought us the productivity increases which led to higher wages and higher incomes.

At the same time it became less easy to replace graduates by staff with less education or by machines, even if those graduates were more expensive and machines became cheaper (Acemoglu, 2002). Today we realize that there is no production without innovative entrepreneurship, without the active participation of people who understand the complexities of society.

This explains why we saw during the period of the fast expansion of the number of graduates in the EU to our great surprise an increased scarcity of graduates. Indeed, more supply which created apparently disproportionably more demand: that is 
surprising. The introduction of mass higher education -driven by social demand- had apparently benefited our societies not only socially, but also economically. ${ }^{3}$

But when sketching this development as a race between technology and education (the term was later copied by Katz and Goldin, 2008) one realizes that technology and education are not two separate race carts, but that it is well trained labor that shapes technology and its applications in production. There is one race cart with higher education as the engine (Aghion and Howitt, 2006).

Saving Europe by means of the universities is about the quality of the engine. We might say that the university engine needs an upgrade to lead to a substantially higher sustainable level of economic growth. An increased quality of higher education and an increased quality and direction of research could bring about a substantial increase in economic growth. It is anybody's guess how much. But it might be as high as some 1-2\% over a period of some decades, if well designed.

We know that education is not about students being enrolled, being registered but about how well students learn (Pritchett, 2002, Barro and Lee, 2002 and Hanushek and Woesmann, 2004). Hanushek and Woessmann (2010) calculate that school improvements in primary and secondary education falling within currently observed performance levels could in the OECD yield through 2090 an additional income of as much as $13.8 \%$ of the discounted value of future GDP.

Autor, Levy and Murnane (2003) found that competencies in performing nonroutine jobs are very important for the labor market (in the sense that they are scarce and as a result well paid for). Yehuda Elkana (2009) argues that graduate education in the humanities should be focused on "understanding the complexities of the world", in order to be relevant for the student.

The general picture for high quality university education is emerging as follows ${ }^{4}$ :

- Cognitive achievement and knowledge of the field remain of prime importance. A graduate who cannot do the job, because he/she is incapable or has not sufficient basic knowledge to be able to learn to do the job is not likely to be employed.

\footnotetext{
${ }^{3}$ The tremendous boon of mass higher education to society was not recognized in the early years of the transition from elite to mass universities (Martin Trow, 1973).

${ }^{4}$ There is no trade off in teaching between talents needed for the labor market and for society (Ritzen, 2012).
} 
- Work is generally done in communication and cooperation with others. Knowing how to work in teams, how to communicate orally and in writing or through electronic media is an essential part of most jobs.

- Employers like graduates in her/his firm to solve the problems which come on their way, to anticipate and to be an entrepreneur and innovator in the firm. Graduates do not function according to a fixed protocol in which it is stated how they allocate their time on different activities, but rather are entrusted with a goal to contribute to the profitability of the firm or the success of their work in a not-for-profit sector.

- A substantial part of the graduates works in an international environment in the sense that they have contacts with suppliers and clients also in other countries.

- Jobs do not have a lifelong existence. The graduate will have to move during his/her active period from job to job and needs to be able to continue to learn for the new job. - Integrity is an important part of the qualities of the graduate.

Preparing students better for these demands of the labor market is the upgrade of the university-for-growth- machine that we are looking for. It requires a different way of working from the side of the university. Universities should be conscious of the huge changes which have taken place on the labor market and which continue to take place.

Recently a storm broke out in the US on its quality of higher education, when a book was published by Arum and Roksa (2011). They did a survey among 2,300 full time students at 24 four-year institutions to find that at least $45 \%$ of students did not improve in a statistically significant way during their first two years of college on the skills assessed by the Collegiate Learning Assessment (CLA): writing, critical thinking, and complex reasoning skills.

This observation cries out for much more systematic measurement. For secondary education the project international student achievement (PISA) has accomplished an international comparison of what students have learned at the age of 15. This has had a tremendous impact on policies in secondary education (Ritzen, 2011). The OECD's Assessment of Higher Education Learning Outcomes (AHELO) project runs along similar lines for university education. It will have an equally strong impact.

When we are clearer about the intended output goals of universities, we can also be more concrete about delivery methods. We know a lot about effectiveness and 
efficiency in delivering university education. Several directions of efficiency improvements present themselves:

- A better use of the student time in study and in learning.

- The use of information and communication technology.

There is ample evidence that problem-based learning is highly efficient for most learners with respect to the combination of professionalism and problem solving. Problem based learning is interestingly taken on board by many medical degree programs, but is rare outside of the medical domain (as far as I know only Aalborg and Maastricht University engage in problem based learning for all degree courses). Case studies are -so it seems- a characteristic of graduate business education, and once again, rare outside business education, despite the proven efficiency. An added feature of problem based learning and case studies is that it induces students to spend more time in studying, while at the same time the learning results per hour are higher.

Information and communication technology (ICT) holds big promises for university learning efficiency improvement. It is almost inescapable that learning efficiency will be improved at some point in the future, simply because of the rising costs of regular education (the Baumol effect). However, the pace of change in universities in adopting more ICT is still very slow: the resistance to reform in universities is overwhelming. Perhaps blended learning is the least threatening. Blended learning is consistent with the values of traditional higher education institutions and has the proven potential to enhance both the effectiveness and efficiency of meaningful learning experiences (Garrison and Kanuka, 2004).

Another potential for efficiency improvement is in dual learning, where work is combined with study. This combination has demonstrated great value in business education (Pham et al, 2010) and in medical education. On the secondary education level Germany has a great tradition in dual education. This tradition has contributed vastly to low youth unemployment and a high level of innovation. There is no reason why universities could also not use this method of dual education to enhance educational efficiency.

European universities spend little or no time on entrepreneurship in degree courses other than those in the business domain, while at the same time it is mostly enterprises which bring both jobs and export earnings. What has been more perplexing is Europe's generally poor performance in the most technology intensive 
sectors - the internet, biotechnology, computer software, health care equipment, and semiconductors. Europe's young leading innovators (called “yollies” for short) are as R\&D-intensive as those in the United States. Europe just has a lot fewer yollies (Gill and Raiser, 2012). Universities and university research should provide a better base for more enterprises and jobs in the high tech areas.

University research in the sciences has played a substantial role in technological advancement, but we should also expect from research in the humanities and social sciences to provide intellectual leadership by more cooperation within and between the different disciplines and by a better tuning to the major societal questions. There is a paradox about intellectual leadership. While the percentage of well trained people in the population grew, intellectual leadership seemed to decline. "Factless politics" (an English language term, which is derived from a Dutch context) roots partly in the disputes between intellectuals among themselves on major issues as well as on the endless fragmentation of sciences. Europe could gain a lot from better knowledge and insight, whether applied to scientific, to social or economic questions, and whether driven by societal curiosity or by economic gains.

A European growth strategy based on knowledge has a shadow side: social cohesion is in danger if no further measures are taken. Social cohesion is the term to indicate to what extent people feel part of society, to what extent they trust that others make their contribution in the same way they do. Often, income inequality is viewed as a measure of social cohesion. The less inequality the more people feel that everyone-gets his or her fair share of the joint effort. Social cohesion has always been looked at as a strong asset of Europe.

The increased contribution of the university to economic growth -as we envision it- implies a better position for graduates on the labor market and the concomitant higher wages earned by graduates ${ }^{5}$. At the same time people with fewer skills will become less secure on the job market and will be less well paid relative to graduates. Income inequality increases and social cohesion decreases. It would be important to take measures to prevent a further rise in income inequality. The Vibrant Europe Forum suggests that this be done in a combination of increasing the incomes

\footnotetext{
${ }^{5}$ Increasing unemployment risks for the unskilled are a fundamental trend in contemporary societies as are decreasing wages, compared to well trained labor (EU Observatory, 2011).
} 
at the bottom and decreasing those at the top of the income distribution. In this way a growth strategy based on knowledge can be combined with a social cohesion strategy.

\section{How to realize the promises of European universities.}

\section{Quiz Question}

What does it take to realize the promises of universities for European sustainable economic growth?

Choose from the following answers:

1. More money (tuition fees and public money).

2. All higher education under EU control and finance.

3 A Higher Education and Research Area with competition between universities and between research groups.

4. More Government control in the member state.

I argued that university education and research can help to recreate in Europe hope and optimism for a bright future. I hasten to say that this is not achieved by more Brussels bureaucracy on top of that of the member-states. Yet, European cooperation could create a better Europe in two ways:

- If member states would learn from each other in terms of what works and what does not work in university policy.

- If university education and research would compete on a European scale. But even more important is the reclaiming of ground by the European intellectuals inside or outside the universities to organize themselves and to overcome the crisis in trust between academia and society (Fresco, 2012).

\subsection{Learning from each other in university policy.}

Up to now European Union countries learn little from each other. They prefer to make their own mistakes, ignoring the experiences of other countries. The Foundation Empower European Universities (EEU), of which I am the founder and chair, is set up to provide a mirror for the Member States so that they can see what they do right and what they do wrong in university policy. EEU is funded in part by the Netherlands Organization for Scientific Research (NWO) and backstopped by Educational Testing Service. It works with a network of 29 correspondents: one in 
each of the EU member countries and two in countries outside the EU which belong to the European Research Area. EEU collects data and analyses the direct impact of Government university policy on the performance of universities in teaching and research from the vantage point of its translation into society. For example, EEU analyzes for EU countries how bureaucratization of universities depresses the innovation of the economy in the country. EEU aims at publishing a annual or biannual State of University Policy for Progress with a "grading” of the university policy of each of the EU's member states, based on the performance and the contribution to economic growth, innovation and competitiveness.

But the information and analysis should be compelling. Governments of EU member states should be held accountable for their policies. There should be correction mechanisms on the European level for obvious bad policies, much like the correction mechanisms for bad macro economic policies. In that way learning from the experiences of other countries could upgrade the university-education-for-growthmachine.

\subsection{Competition in education.}

Learning from each other with European correction facilities is a form of regulation. We can also use the forces of competition, either in addition or as an alternative. The idea behind competition is that students should be well informed about the qualities of individual university degree courses in Europe and are free to choose where they want to study, while the financial conditions are the same as if they would study in their home country. Subsequently, the universities which are good at attracting students are rewarded.

The forces of competition in Europe in Higher Education have not been exploited, mostly because the quality of higher education has been difficult to measure. Increasingly, however, good measures are available, not in the least thanks to the EU-project on Multidimensional Ranking (van Vught and Ziegele, 2012) and the OECD’s AHELO project. Competition would create an upward quality spiral, increase student mobility and prepare students better for an increasingly international labor market.

The creation of a new type of Erasmus program (let us call it Erasmus 3.0) in which around $10 \%$ of the universities of individual member countries of the EU 
would be governed by EU legislation and partly financed through European funds by 2020 would be a step towards an EU with university quality competition.

\subsection{Public university research.}

For public research the case is simpler: it should be governed at a European level. There are clear disadvantages of small scale in many public research areas. The current existence of a European Research Council (ERC), next to 27 individual national research councils, each limited in their research calling, in selection of submitted proposals and in the granting of research funds to their respective national geographical boundaries, is very inefficient.

Research excellence is heavily dependent on scale: the European scale seems to be the most logical scale for most publicly funded research activities, for reducing the costs in selecting and evaluating research proposals and for enabling high quality research specialization (Ritzen and Soete, 2011). At the same time social security and pension provision for universities should be organized on a European scale to allow for full mobility of university staff.

Pan-European higher education and public research has the substantial promise to contribute to a "saving of Europe" through the universities. It is a matter of conceiving the transition from knowledge strategies which are mostly country specific with the idiosyncrasies of overlap and insufficient adjustment to the globalization of knowledge towards a common policy which ensures cohesion and convergence in a sustainable growth strategy. It is also a matter of gaining the political support for this direction, because it means a different interpretation of subsidiarity. Subsidiarity has been interpreted as: this is no business for Europe, because we have not included it in the treaty as a European concern. Yet, the original concept of subsidiarity implied that whatever can be better done at the national scale should be done there. University education and research can better be implemented by the member states. But they need a European framework in order to achieve a vibrant Europe.

The bureaucracy of European research is at present stifling, because every European project and program has to be handled as one size fits all. A vibrant Europe relies on the procedures in the home country for the allocation and accounting of research funds. The political support for more Europe is heavily dependent on the ability of Europe to act decentralized in the implementation of the European framework. 
The intellectual leadership role of universities seems to have dried up and needs to be redeployed for a vibrant Europe. Universities have done too little to show their hand in concentrating on major societal questions and coming up with potential answers. In particular the role of social science and humanities research could be strengthened. This is part of the broader loss of trust between academia and society, despite the major improvements which have taken place in university education and research. The voice of national organizations of universities, like "Rectors

Conferences" or university associations or of international organizations is not heard in politics. Europe society interprets this voice principally as self serving, while at the same time university rectors and presidents have little respect for the political leadership. They claim that the best social outcome from universities is realized by giving full autonomy to universities, without interference from Government.

The university that saves Europe is besides being part of a European space of competition also trusted by society. That university is governed indeed by autonomy and not by detailed bureaucratic regulation, but with a clear understanding from society that the university is looking towards the future, focused on societal questions and constantly adjusting to the changes that are taking place in that society -even if this means serious and possibly painful changes in the own house.

We need in Europe a new pact between politics and universities, which relieves universities of the pressure of the electoral cycle, while still living up to the expectations of society. Such a pact also requires that universities are willing to take the responsibility for far more drastic changes than have been brought about in the past. European universities should do away of the exclusion which national languages bring about and revert to one European language.

Finally, it is obvious that universities can contribute much more to a vibrant Europe if they would be better funded by public and private means. This applies both to university education as to research. Additional funding is an investment with a substantial return for the European societies.

\section{The bull by the horns.}


Thai fishermen say that they "save fish from drowning” as an excuse for taking fish from their natural habitat. Euro-skeptics may say that the preceding has been an excuse, a self-serving goal of the leftist Church to take European citizens out of their national habitat. Intellectuals should stand up against this reasoning, organize themselves and make it clear that broader, deeper and better European cooperation is the only no-regret scenario for a vibrant future. In such a vibrant future, Europe continues to be relevant on the world stage and can thus ensure a future of sustainable prosperity for ourselves, out children and grandchildren. Without explicit action, Europe's relevance will decline and living in Europe will become less attractive.

The poet Ovid wrote of Jupiter, the Roman king of the gods, who tried to hide his proclivity for young women from his wife Hera by disguising himself as a white bull when abducting the young Maiden Princess by the name of Europa from what is now Lebanon. That image can be paraphrased when thinking of Europe as a frightened Maiden, taken for a ride by the bull of globalization:

“... The frightened Maiden looks backward on the shore, And hears the tumbling billows round her roar;

But still she holds him fast: one hand is born Upon his back; the other grasps a horn:

Her train of ruffling garments flies behind, Swells in the air, and hovers in the wind. ...”

And see: Ovid lets her grasp the horns on the bumpy ride. Grasping the horns during a bumpy ride means being well aware of the popular distrust of politicians, and of the failure of European institutions to demonstrate efficiency. For example, by doing away with the indulgence of a two-seat European Parliament, and with the leaden burden of working in 23 languages.

Knowledge is central for a European future full of promises. Universities can play a decisive role in creating that vibrant European future, if properly empowered.

\section{My gratitude.}


My gratitude for this appointment goes first to the Executive Board of Maastricht University, who decided that they could entrust me with this mission, even though they know me well as colleagues in the Board. Professor Luc Soete, the proto type professor who can save Europe, provided administrative, mental and financial space to spread my wings in the School of Governance for the Vibrant Europe Forum and the Foundation Empower European Universities. I am most grateful to him as I am also to Professor Klaus F. Zimmermann who provided me similar space at the Institute for the Study of Labor in Bonn.

There is long list of persons I consider as my academic mentors, most of them having passed away: Professors Jan Tinbergen, Kees Verhagen, Huibert Kwakernaak, Charles Benson, Fred Balderston and Dik Wolfson. In making knowledge useful to society I have learned a lot from my work at the Social and Cultural Planning Office, but also from the politician Joop den Uyl. Wim Kok has had a great impact on the shaping of my mind in the eight plus years I served as a minister. I have enjoyed the company and inspiration of many in the World Bank, notably Jim Wolfensohn, Joe Stiglitz, Nick Stern and David de Ferranti. Maastricht University has been far more exciting than I ever expected it to be, with the support of the Supervisory Board of whom I mention Sjeng Kremers and Peter Elverding. But the excitement came really from the spirit and dedication of both the academic and the non-academic staff to do the best possible in teaching and research in an international setting.

The more removed in time I get from my youth, the more I see that time as decisive for what I do now. My family, my father the teacher and eternal learner who believed that only education counted in life. My mother, also a teacher with strong values on the importance of family and always with loving care. My sister Leny, who under other circumstances might have preceded Margeret Thatcher. My sister Jos who died too early. My brother Jan, my companion in the search for our distant roots and my brother Wim whose company I enjoy now more than in the past forty years as we are living closer. I owe them all beyond measure.

Yet it is a special pleasure to thank here my children and grandchildren, Rafiq, Carlijn, Michiel en Maaike and the seven whose first initials make up an unbeatable password. I thank them for the education I received from them, by providing me with the mirror of my actions and personality. And Hanneke, my companion of now almost 45 years. I owe you the most for your support and love. 


\section{References.}

Acemoglu, Daron, “Technical Change, Inequality and the Labor Market”, Journal of Economic Literature, Vol. 40, pp. 7-72, March 2002.

Aghion, Philippe and Peter Howitt, “Appropriate Growth Policy: A Unifying Framework", Journal of the European Economic Association, Vol. 4, no 2-3, pp. 269314, 2006.

Arum, Richard and Josipa Roksa, Academically Adrift: Limited Learning on College Campuses, Chicago: University of Chicago Press, 2011.

Autor, David H., Frank Levy and Richard J. Murnane, “The Skill Content of Recent Technological Change: An Empirical Exploration”, Quarterly Journal of Economics, Vol. 118, no 4, 2003.

Barro, R. and J. Lee, "International Data on Educational Attainment: Updates and Implications", working paper no. 42, center for International Development, Harvard University, 2002.

Elkana, Yehuda, "Freedom and Interdisciplinarity: the Future of the University Curriculum”, Social Research, Vol. 70, no.3, pp 933-942, Fall 2009.

European Social Observatory, OSE Opinion Paper N5 - May 2011.

Fresco, Louise O., "Professors and Politicians” (in Dutch), NRC, p. 14, Febr. 13, 2012.

Fuchs, Dieter, Isabelle Guinaudeau and Sophia Schubert, "National identity, European identity and Euroscepticism”, in: Fuchs, Dieter, Magni-Berton, Raul, Roger, Antoine (Eds.): Euroscepticism. Images of Europe among mass publics and political elites, Opladen \& Farmington Hills, MI: Barbara Budrich Publishers, pp. 91112, 2009.

Garrison, D. Randy and Heather Kanuka, "Blended learning: uncovering its transformative potential in higher education”, Internet and Higher Education , pp. 95105, 2004.

Gill, Indermit and Martin Raiser, Restoring the lustre of the European economic model, Worldbank, 2012.

Goldin, Claudia and Lawrence F. Katz, "The Race between Education and Technology: The Evolution of U.S. Educational Wage Differentials, 1890 to 2005”, Harvard University and National Bureau of Economic Research, 2009.

Hanushek, Eric, A. and Ludger Woessmann, "How Much Do Educational Outcomes Matter in OECD Countries?” NBER Working Papers 16515, 2010. 
Israeli, Jonathan, A Revolution of the Mind, Princeton: Princeton University Press, 2010.

Koenis, Sjaak, “The democratization of resentment”, (in Dutch), Inaugural Lecture, Maastricht University, March 1, 2012.

Kufer, Astrid, “The Intellectual Discourse on European Identity”, in: Fuchs, Dieter, Magni-Berton, Raul, Roger, Antoine (Eds.), Euroscepticism. Images of Europe among mass publics and political elites, Opladen \& Farmington Hills, MI: Barbara Budrich Publishers, p. 47, 2009.

Levin, Henry, M, “The Utility and Need for Assessing Non Cognitive Skills in Large - Scale Assessments”, in Irwin Kirsch , Kentaro Yamamoto and Eugenio Ganzalez, (editors), The Role of International Large-Scale Assessments, Springer, 2012.

Lubbers, Marcel and Peer Scheepers, "Divergent Trends of Euroscepticism in coubntries and regios in the European Union”, European Journal of Political Research, Vol. 49, pp. 787-817, 2010.

Manifesto Empower European Universities, www. empowereu.org, June 2010.

OECD, Growing Unequal?, 2008.

OECD, Divided We Stand, 2011.

Pham, Nga T.P., Mien S. R. Segers and Wim H. Gijselaers, "Understanding Training Transfer Effects from a Motivational Perspective: A Test of MBA Programmes”, Business Leadership Review, VII:III, July 2010.

Pritchett, Lant, "Where has all the education gone", The Worldbank Economic Review, Vol 15, no. 3, pp. 367-391, 2001.

Ritzen, J.M.M., Population, public sector and economy, Inaugural Lecture Erasmus University, VUGA, 1983.

Ritzen, Jo, A Chance for European Universities, Amsterdam University Press, 2010.

Ritzen, Jo and Luc Soete, - Research, Higher Education and Innovation: Redesigning European Governance in a Period of Crisis, Policy Paper, Notre Europe, Nov. 2011.

Ritzen, Jo, A Renaissance for Social Mobility and its Significance for the Bridge towards Postsecondary Education, ETS / SGS Seminar, "Optimizing Talent: Closing Education and Social Mobility Gaps Worldwide", Salzburg, December 6-11, 2011.

Ritzen, Jo , "Large-Scale Assessments as Change Agents”, in Irwin Kirsch, Kentaro Yamamoto and Eugenio Ganzalez, (editors), The Role of International Large-Scale Assessments, Springer, 2012. 
Ritzen, Jo and Klaus F.Zimmermann, “Fading hope in the US”, IZA Paper, 2012.

Ritzen, Jo, “ Preparing Students for the Demands of Labor Market”, 3rd International Exhibition and Conference on Higher Education, World Class Teaching Universities, 17 - 20 April 2012, Riyadh - Saudi Arabia, 2012.

Tinbergen. J., Income Distribution, Amsterdam, North Holland, 1975.

Trow, Martin, "Problems in the Transition from Elite to Mass Higher Education”,Carnegie Commission on Higher Education, 1973.

Truedinger, "Have They Gone Too Far? Attitudes towards the Transfer of Policies on the EU Level”. In: Fuchs, Dieter, Magni-Berton, Raul, Roger, Antoine (Eds.):

Euroscepticism. Images of Europe among Mass Publics and Political Elites, Opladen \& Farmington Hills, MI: Barbara Budrich Publishers, p. 151, 2009.

van Vught, Frans A. and Frank Ziegele, Multidimensional Ranking: The Design and Development of U-Multirank, Springer, 2012.

The comments by Lex Borghans, Arian Meyer, Michiel Ritzen and Klaus

Zimmermann have greatly improved an earlier draft. 